\title{
Assessing the potential of natural woody species regeneration for the conversion of Norway spruce plantations on alluvial soils
}

\author{
Bruno HÉRAUlT ${ }^{a}$, Daniel THOEN ${ }^{\mathrm{a}}$, Olivier HONNAY ${ }^{\mathrm{b}}$ \\ ${ }^{a}$ Department of Environmental Sciences \& Management, University of Liège, Avenue de Longwy 185, 6700 Arlon, Belgium \\ b Laboratory for Forest, Nature and Landscape Research, University of Leuven, Vital Decosterstraat 102, 3000 Leuven, Belgium
}

(Received 23 February 2004; accepted 15 June 2004)

\begin{abstract}
In the perspective of the conversion of Norway spruce plantations, there is a need for foresters to assess the potential of the natural woody species regeneration. We studied 50 Norway spruce plantations on alluvial soils throughout the Grand-duché de Luxembourg and compared the regeneration characteristics (species composition, spatial heterogeneity) with 42 riverine deciduous stands (the target communities). Within the Norway spruce plantations, Fraxinus excelsior and Acer pseudoplatanus were the main regenerating species, probably because of their very good dispersal abilities. Norway spruce seedlings were quasi-absent. Low Norway spruce densities and baserich soils (local factors) as well as proximity of riverine deciduous forests (regional factor) strongly favoured the regeneration of a suite of broad-leaved species. The thickness of Norway spruce litter did not appear to be a limiting factor, at least for large-seeded tree seedlings. The spatial heterogeneity of the woody regeneration was rather similar in coniferous and deciduous stands. We conclude that for the development of multifunctional forests, the spontaneous regeneration under low-dense Norway spruce stands on base-rich soils provides a valuable starting point.
\end{abstract}

Picea abies / floodplain / spontaneous rejuvenation / spatial heterogeneity / Luxembourg

Résumé - Évaluation des potentialités de régénération naturelle pour la conversion des plantations d'épicéas sur sols alluviaux. Dans une perspective de conversion des plantations d'épicéas, les forestiers ont besoin d'évaluer les potentialités de régénération naturelle. Nous avons étudié 50 plantations d'épicéas sur sols alluviaux au grand-duché de Luxembourg et comparé les caractéristiques de cette régénération naturelle (composition, hétérogénéité spatiale) à 42 forêts riveraines de feuillus (communautés de référence). Dans les plantations d'épicéas, Fraxinus excelsior et Acer pseudoplatanus sont les principales espèces qui régénèrent, probablement en raison de leur grande capacité de dispersion. Les jeunes épicéas sont quasiment absents. La régénération des essences feuillues est fortement favorisée par de faibles densités d'épicéas, par des sols riches en bases (facteurs locaux) et par la proximité de forêts alluviales (facteur régional). La litière de l'épicéa ne semble pas être un facteur limitant à la régénération, au moins pour les essences à grosses graines. L'hétérogénéité spatiale de la régénération est très similaire dans les peuplements de feuillus ou d'épicéas. En conclusion, la régénération spontanée d'essences feuillues sous les plantations d'épicéas peu denses et établies sur des sols basiques est un point de départ très intéressant dans un processus de conversion de ces plantations vers des forêts multifonctionelles.

Picea abies / plaine alluviale / régénération naturelle / hétérogénéité spatiale / Luxembourg

\section{INTRODUCTION}

Norway spruce has been widely planted in Western and Central Europe for the last two centuries. Moreover, in part as a direct consequence of the Common Agricultural Policies of the European Union of the last fifty years, former alluvial meadows annually mown either have been abandoned to natural colonisation or have been converted into Norway spruce or Poplar plantations. Due to biodiversity considerations [30] and to significant damage to Norway spruce resulting from storms and insect proliferation [34], the current tendency to convert Norway spruce plantations into more spontaneous forests is in the first place. Indeed, Norway spruce plantations on alluvial soils (i.e. located in the floodplain) do generally not fulfil most of the current requirements of multifunctional forestry i.e., wood production, recreation, nature conservation, hunting, water supply and soil protection [22]. In this context, conversion of these plantations is a great challenge both for forest managers and ecologists in Europe.

All over the world, initiatives to restore the formerly present forest type on areas covered by plantations have significantly increased during the last decade (e.g. [2, 48]). In Europe, several studies have been conducted on the natural regeneration

\footnotetext{
* Corresponding author: herault@ful.ac.be
} 


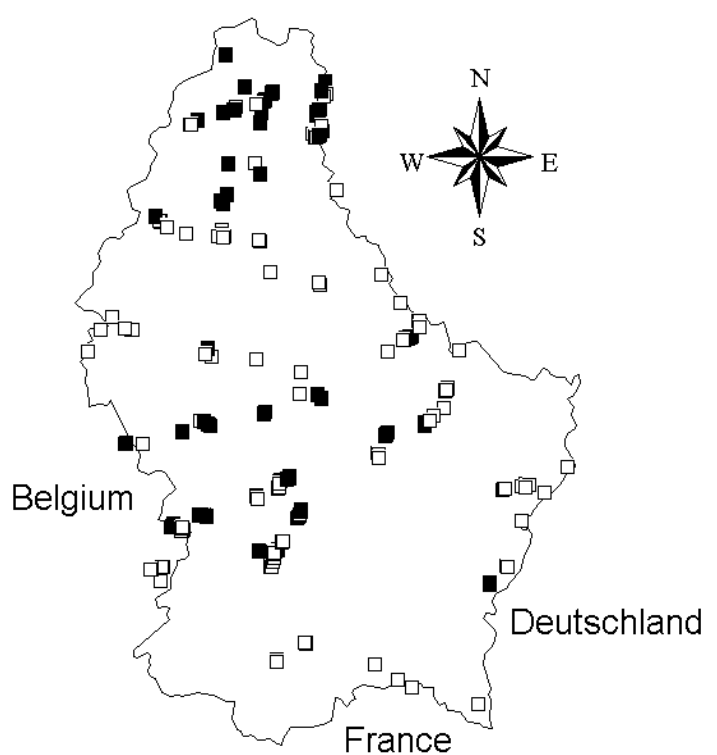

Figure 1. Location of the studied sites (Norway spruce stands: filled dots; deciduous stands: empty dots) throughout the Grand-duché de Luxembourg.

processes under Norway spruce $[3,15,28,34,60]$, Pine (e.g. [44]), or Poplar plantations (e.g. [40, 61]). All these species have been intensively planted outside of their native biogeographical area and, frequently, on unsuitable sites. Generally these studies concluded that non-indigenous plantations facilitate the regeneration of indigenous trees under their canopy. However, apart from one prior qualitative study [28], regeneration processes in Norway spruce plantations on alluvial soils have not been studied quantitatively to our knowledge. Because foresters need to understand the potential of natural regeneration in the perspective of conversion, we addressed the following questions: (i) Which woody species regenerate naturally in Norway spruce plantations on alluvial soils? (ii) Is this regeneration qualitatively and quantitatively comparable to the regeneration observed in deciduous alluvial stands? (iii) Which stand characteristics explain the level of regeneration? (iv) Is this regeneration homogeneous enough to be useful in order to convert Norway spruce plantations into deciduous alluvial woods?

\section{MATERIALS AND METHODS}

\subsection{Study area}

Almost all the investigated stands were situated throughout the Grand-duché de Luxembourg in Central-Western Europe (49 $26^{\circ}$ $\left.-50^{\circ} 10^{\prime} \mathrm{N}, 5^{\circ} 42^{\prime}-6^{\circ} 32^{\prime} \mathrm{E}\right)$. The climate is continental with an oceanic influence; the mean annual temperature is $9^{\circ} \mathrm{C}$. Annual rainfall ranges between $700 \mathrm{~mm}$ (East) and $1000 \mathrm{~mm}$ (West). From geographical and geological viewpoints, Luxembourg has two natural regions, which are extensions of Belgian biogeographical regions [18]. In the North, the 'Oesling' consists of Lower Devonian geological layers, shales and gritty shales with low calcium and phosphorous contents.
The 'Oesling' covers one-third of the territory, is slightly mountainous (highest point: $555 \mathrm{~m}$ ) and is heavily forested. The South, called 'Gutland', has more recent geological layers of sandy and calcareous rocks, from the Triassic and Jurassic periods. It mainly consists of rolling farmlands and small forests as an extension of the Lorraine plateau.

Tree species of deciduous forests on alluvial soils are mainly Fraxinus excelsior, Acer pseudoplatanus, Quercus robur, Alnus glutinosa and sometimes Fagus sylvatica and Carpinus betulus. Ulmus minor has almost disappeared from the tree layer as a result of Dutch Elm disease. Crataegus spp., Corylus avellana, Prunus padus, and Sambucus spp. form a well-developed woody undergrowth [28].

\subsection{Sampling methods}

Norway spruce plantations were systematically selected with regard to similar stand ages (ca. 45 years old). Deciduous stands (i.e. the target communities for conversion of Picea stands) were selected only if no visual sign of a former plantation was present. Almost all the stands were distributed throughout the GDL in a spatially extensive sampling strategy [10]. In total, 86 Norway spruce plantations, ranging from 840 to $14570 \mathrm{~m}^{2}$, and 160 deciduous stands, ranging from 500 to $12190 \mathrm{~m}^{2}$, were surveyed (Fig. 1). Stand areas were estimated using digitised maps. The fieldwork was carried out during the growing period 2002 and 2003.

All stands were completely and systematically surveyed twice a year: during spring and during summer/autumn. All plant species were recorded. Forest margins were omitted. Each species received an abundance coefficient. Low, medium and high surface cover of the stand were coded respectively as $1(<10 \%), 2(10$ to $50 \%)$, and 3 $(>50 \%)$. Cover percentages of both the herbaceous and the canopy layers were also recorded. The nomenclature of vascular plants follows Lambinon et al. [38]. The whole vegetation table is available from the authors upon request.

In a subset of 50 randomly selected Norway spruce plantations and 42 deciduous stands, the individual numbers of regenerating trees and shrubs were recorded. In each stand, 3 randomly chosen replicates of $5 \mathrm{~m} \times 5 \mathrm{~m}$-sized plots [44] were established. Tree and shrub species were registered and classified into four categories: young seedlings ( $<10 \mathrm{~cm}$ tall), old seedlings ( $\geq 10 \mathrm{~cm}$ but $<50 \mathrm{~cm}$ tall), short saplings ( $\geq 50 \mathrm{~cm}$ but $<1.5 \mathrm{~m}$ tall), tall saplings $(\geq 1.5 \mathrm{~m}$ tall but $<7 \mathrm{~cm} \mathrm{dbh}$ ).

For the 86 Norway spruce plantations, two types of environmental characteristics were registered: (i) regional ones: distance to the nearest deciduous forest, distance to the nearest alluvial deciduous forest (i.e. forest occurring in the floodplain of the same river) and (ii) local ones: the basal surface using the Bitterlich relascop, the tree density extrapolated from a $20 \mathrm{~m} \times 20 \mathrm{~m}$ subplot, the tree maximum height determined with a clinometer, the soil texture (relative \% of clay, silt and sand) hand-estimated in the field, the soil pH (ISO 10390 norm), the humus type [17] and, if present, the depth of apparition of the reduction level in the soil.

\subsection{Statistical analyses}

(i) As vegetation and ecological processes on alluvial soils were rather heterogeneous within both Norway spruce plantations [47] and deciduous stands [46, 49], a prior site classification was applied for both forest types. In order to provide a comprehensible and applicable classification based on forest trees for forest managers, deciduous stands were classified based on the woody species abundances. Norway spruce plantations were classified based on the herbaceous vegetation abundances because this layer is sometimes the only one present and hence a classification based on woody species is futile. Ward's method, which minimizes distortions in the underlying space [41], was chosen for clustering. The indicator value (IV) method was 
(a)

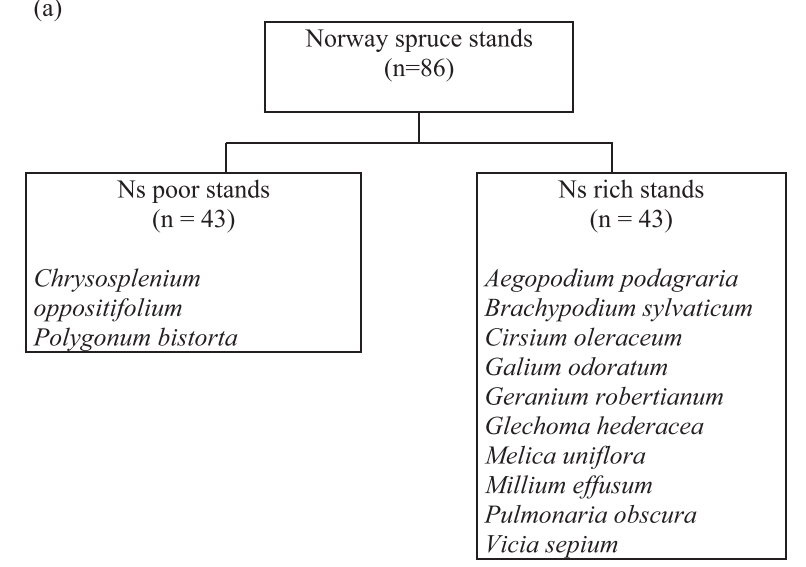

Figure 2. Cluster analyses of (a) Norway spruce stands based on herbaceous species abundances and of (b) deciduous stands based on woody species abundances (Ward's method, indicator species determined following Dufrêne and Legendre [19], only species with $P<0.001$ are reported). used to detect the specificity of a species for a certain cluster [19]. The statistical significance of the IV is evaluated using a randomisation procedure performed with 99999 permutations.

(ii) Even if our stand areas were largely superior to those recommended for forest vegetation studies [8], the variability of sampling areas could affect the number of herbaceous species recorded. To rule out this problem when studying the relationships between Norway spruce clusters and numbers of species, two linear regressions (one for each cluster) were conducted with the logarithm of stand area (the logarithm allowed a better significance of the regression) as independent variable and the number of species as dependent variable.

(iii) Differences of mean (when data fitted normality) or median (when data did not) values of local and regional characteristics were tested between the two clusters in order to get a thorough ecological profile of each type. Fisher exact test, $t$-test, $\mathrm{Chi}^{2}$ and Mann-Whitney $\mathrm{U}$ test were applied depending on the data type.

(iv) For each cluster group of the main forest types, sapling data of the spontaneous tree regeneration and of the shrub species were arranged into box plots with medians and quartiles (data did not fit normality). At this step of the analysis, only the sapling dataset was included because the potential of seedlings is uncertain for forestry. Plot data were averaged per stand to avoid risks of pseudo-replication [31].

(v) We used a Spearman rank correlation coefficient to get an insight into the role of environmental characteristics (cover of herbaceous and canopy layer, litter thickness, soil $\mathrm{pH}$, plantation density, distance to the nearest forest and to the nearest alluvial forest) in the regeneration densities of woody species observed under Norway spruce canopy. As F. excelsior and A. pseudoplatanus were the main regenerating trees, analyses were carried out first for these two species separately and then on the pooled other species.

(vi) To investigate the spatial distribution of the woody species regeneration in each site, the Morisita index $(I)$ [43] was used. To avoid too many null values, data were analysed for all trees useful for forestry together (i.e. A. pseudoplatanus, C. betulus, F. excelsior, F. sylvatica and $Q$. robur). $I$ was applied by developmental stage and by site:

$$
I \delta=\frac{m \sum_{j=1}^{m} n_{j}\left(n_{j}-1\right)}{N(N-1)}
$$

where $m=$ number of plots, $n_{j}=$ the number of individuals found within the $j$ th plots, and $N=$ the total number of plots. This index reflects a regular $(I \delta<1)$, a random $(I \delta=1)$, or an aggregated $(I \delta>1)$ distribution. The maximum value of $I \delta$ is $m$. The significance of $I \delta$ deviation is tested by:

$$
T=\frac{I \delta(N-1)+m-N}{m-1} .
$$

$T$ is compared with a $F$-table $(m-1 ; \infty)$. The deviation from random distribution was chosen significant for $T>F_{(m-1 ; \infty)}$ with $\alpha=0.05$.

\section{RESULTS}

\subsection{Typology of the stands}

Simplified classifications for the first levels of division of the cluster analysis are given in Figure 2. Norway spruce plantations were classified in two groups of stands. Within the two 


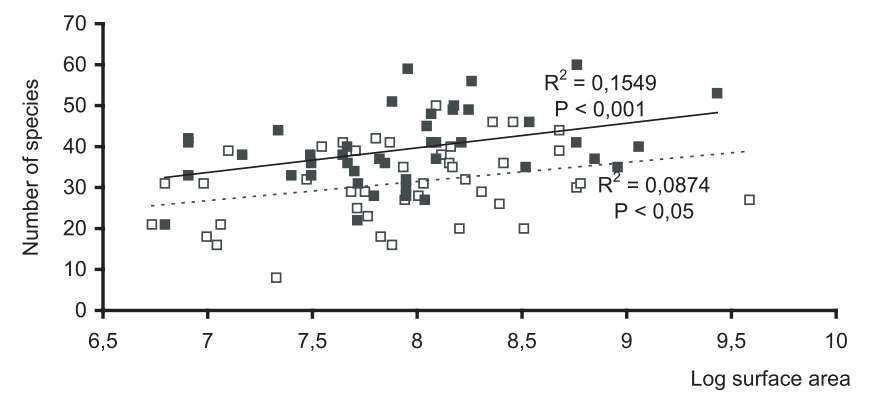

口 Ns poor stands $(n=43)$

- Ns rich stands $(n=43)$

L Linear regression (Ns rich stands)

.... Linear regression (Ns poor stands)

Figure 3. Relationships between herbaceous species numbers and stand areas within the two clusters of Norway spruce stands.

clusters, the herbaceous species richness was positively related to the logarithm of stand area (Fig. 3). At low areas, species richness increased rapidly, but the rate of increase declined with increase in area. On the whole, the difference between the two regression lines averaged 10 species. Based on this result, the first and the second cluster will be referred to as 'Ns poor stand' and 'Ns rich stand', respectively. Ns poor stands were characterized by only two herbaceous species (Fig. 2) whereas a lot of abundant species in Ns rich stands were absent in Ns poor stands. The latter were predominant in the Oesling region and had a higher density of mature Norway spruce trees (Tab. I). Soils of rich stands were drier (as the reductive layer appeared deeper) and sandier whereas those of poor stands were wetter, and richer in clay and silt. Although the mean distance to the nearest forest was quite similar between the two groups, the mean distance to the nearest alluvial forest differed greatly. Indeed, within the floodplain, Ns poor stands were more isolated from deciduous forest than Ns rich stands.

Deciduous stands were classified into 3 distinct clusters. Stands characterized by Fagus sylvatica, Carpinus betulus and Quercus robur (Beech stands) clearly clustered into one type. The residual stands were separated in 2 groups, i.e. into Alder stands on the one hand and Ash stands on the other. On the whole, this classification followed a hydrological gradient from the very wet $A$. glutinosa stands to the drier $F$. sylvatica stands.

\subsection{Quantification of the natural regeneration}

In total, 34 woody species were present in Norway spruce plantations while 31 were in deciduous stands. The frequencies and abundances of saplings for the different clusters are shown in Figure 4. A particular characteristic of the Norway spruce plantations was the presence of few (1-3) dominant tree species in composition of the regeneration. Thus variation in relative abundance of the total numbers of tree seedlings and saplings often reflected variations of these dominant species.

Table I. Influences of regional and local environmental factors on the types of Norway spruce stands derived from the clustering (Fig. 2).

\begin{tabular}{|c|c|c|c|c|c|}
\hline & Unit & $\begin{array}{l}\text { Ns poor stand } \\
\quad(n=43)\end{array}$ & $\begin{array}{c}\text { Ns rich stand } \\
\quad(n=43)\end{array}$ & $P$ & Test \\
\hline \multicolumn{6}{|l|}{ Biogeographical region } \\
\hline Gutland & Number of sites & 7 & 43 & $* * *$ & Fisher exact test \\
\hline Oesling & & 36 & 0 & & \\
\hline \multicolumn{6}{|l|}{ Regional variables } \\
\hline Distance to the nearest forest $\mathrm{t}^{\mathrm{a}}$ & $\mathrm{m}$ & 15 & 10 & ns & Mann-Whitney U test \\
\hline Distance to the nearest alluvial forest $\mathrm{t}^{\mathrm{a}}$ & $\mathrm{m}$ & 846 & 78 & $* * *$ & Mann-Whitney U test \\
\hline \multicolumn{6}{|l|}{ Forestry characteristics } \\
\hline Stand area ${ }^{b}$ & $\mathrm{~m}^{2}$ & $3324 \pm 2305$ & $3358 \pm 2291$ & ns & $t$-test \\
\hline Basal surface ${ }^{b}$ & $\mathrm{~m}^{2} \cdot \mathrm{ha}^{-1}$ & $59 \pm 12$ & $51 \pm 15$ & $*$ & $t$-test \\
\hline Density ${ }^{b}$ & trees $\cdot \mathrm{ha}^{-1}$ & $1453 \pm 0807$ & $940 \pm 411$ & $* * *$ & $t$-test \\
\hline Height of dominants ${ }^{b}$ & $\mathrm{~m}$ & $32 \pm 07$ & $35 \pm 07$ & $*$ & $t$-test \\
\hline \multicolumn{6}{|l|}{ Soil characteristics } \\
\hline Clayb & $\%$ of soil & $61 \% \pm 37 \%$ & $17 \% \pm 28 \%$ & $* * *$ & $t$-test \\
\hline Silt $^{b}$ & $\%$ of soil & $27 \% \pm 29 \%$ & $28 \% \pm 21 \%$ & ns & $t$-test \\
\hline Sand $^{b}$ & $\%$ of soil & $12 \% \pm 20 \%$ & $55 \% \pm 30 \%$ & $* * *$ & $t$-test \\
\hline $\mathrm{pH}^{\mathrm{b}}$ & pH unit & $5,4 \pm 0,8$ & $6,2 \pm 1,2$ & $* * *$ & $t$-test \\
\hline \multicolumn{6}{|l|}{ Depth of the reduction level } \\
\hline $\mathrm{d}<50 \mathrm{~cm}$ & \multirow{2}{*}{ Number of sites } & 30 & 7 & $* * *$ & $\mathrm{Chi}^{2}$ test \\
\hline $\mathrm{d} \geq 50 \mathrm{~cm}$ & & 13 & 36 & & \\
\hline \multicolumn{6}{|l|}{ Type of humus } \\
\hline Mull & \multirow{2}{*}{ Number of sites } & 8 & 23 & $* * *$ & $\mathrm{Chi}^{2}$ test \\
\hline Moder \& Mor & & 35 & 20 & & \\
\hline
\end{tabular}

a Values are medians.

b Values are means.

ns: $P>0.05 ; * 0.01<P<0.05 ; * * 0.001<P<0.01 ; * * * P<0.001$ 

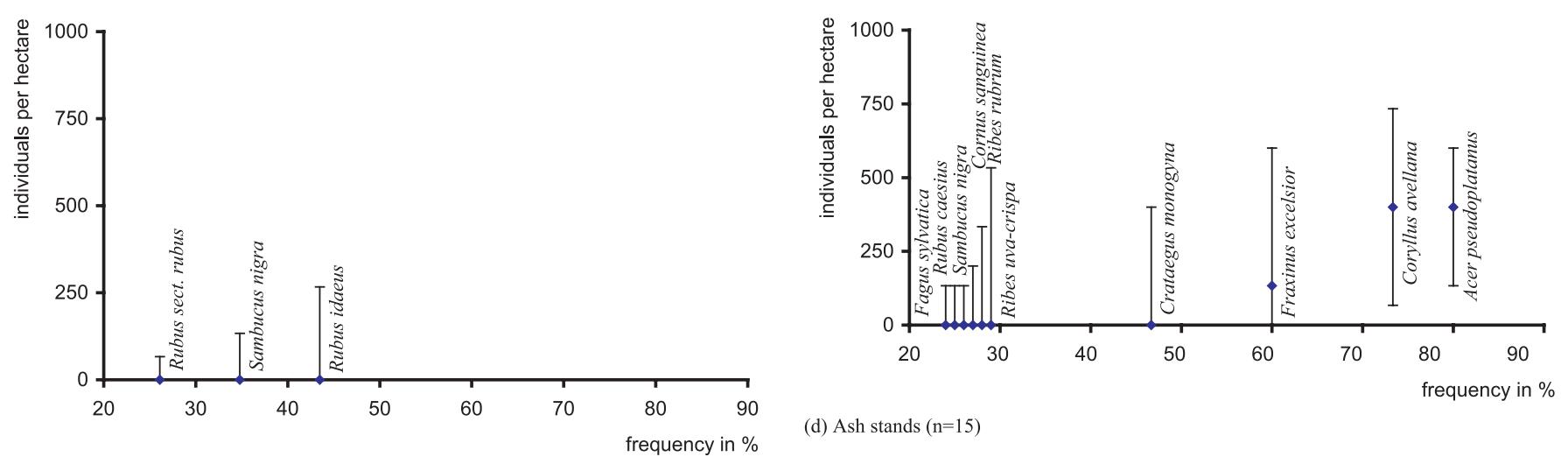

(a) Norway spruce poor stands ( $\mathrm{n}=23$ )
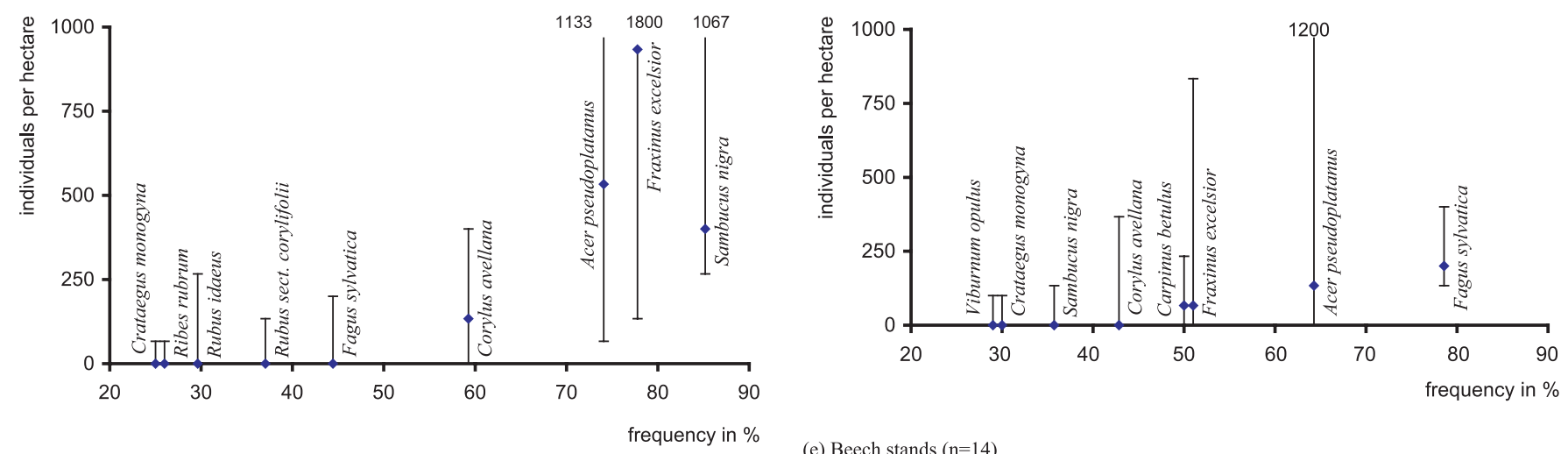

(e) Beech stands $(\mathrm{n}=14)$

(b) Norway spruce rich stands $(\mathrm{n}=27)$

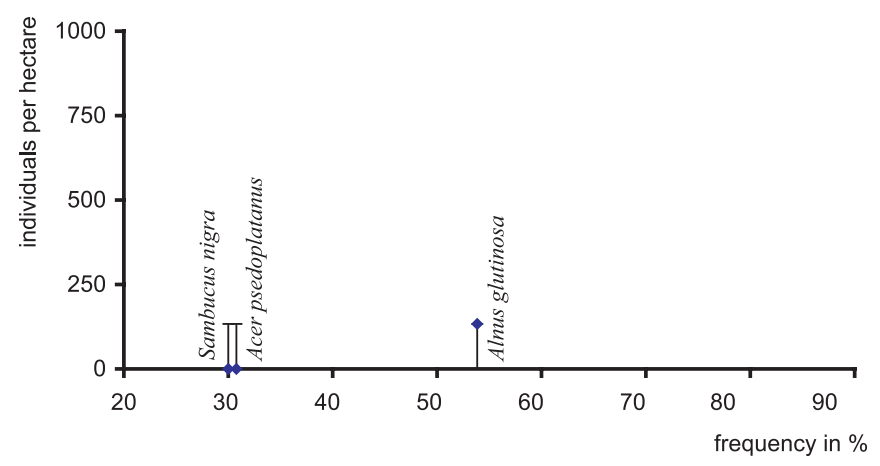

(c) Alder stands $(\mathrm{n}=13)$

The regeneration patterns were highly differentiated (Figs. 4a and $4 \mathrm{~b}$ ) between the two clusters of Norway spruce plantations. For Ns rich stands, in addition to the spontaneous regeneration of the shrub Sambucus nigra, the tree saplings $F$. excelsior and A. pseudoplatanus were found most frequently. In $50 \%$ of plantations, more than 500 saplings of A. pseudoplatanus were recorded per hectare while almost 1000 saplings of $F$. excelsior were observed. F. sylvatica, with frequencies lower than $50 \%$, and Q. robur or C. betulus, with frequencies lower than $20 \%$, were not abundant. The pool of tree species regenerating spon-

Figure 4. Frequencies of saplings, and medians $(\bullet)$ and quartiles of individual numbers of saplings per hectare in both Norway spruce $(\mathrm{a}, \mathrm{b})$ and deciduous $(\mathrm{c}, \mathrm{d}, \mathrm{e})$ clusters.

taneously in Ns poor stands was rather low. Neither trees nor shrubs regenerated frequently to such an extent that none tree species appeared in Figure 4a. Spontaneous regeneration of Picea abies was negligible in the investigated Norway spruce plantations.

The three clusters of deciduous stands were also highly differentiated (Figs. 4c, 4d and 4e). Tree saplings were generally rare in the Alder group. Only A. glutinosa and A. pseudoplatanus regenerated slightly. Conversely, Ash and Beech stands had high numbers of regenerating trees. Within Ash stands, 
Table II. Spearman rank correlations $(r)$ between densities of woody juveniles in Norway spruce stands and local and regional variables.

\begin{tabular}{|c|c|c|c|c|c|c|c|c|c|c|c|c|c|c|}
\hline & \multicolumn{2}{|c|}{$\mathrm{CH}^{\mathrm{a}}$} & \multicolumn{2}{|c|}{$\mathrm{CT}^{\mathrm{a}}$} & \multicolumn{2}{|c|}{$\mathrm{DF}^{\mathrm{a}}$} & \multicolumn{2}{|c|}{$\mathrm{DAF}^{\mathrm{a}}$} & \multicolumn{2}{|c|}{$\mathrm{LT}^{\mathrm{a}}$} & \multicolumn{2}{|c|}{$\mathrm{PD}^{\mathrm{a}}$} & \multicolumn{2}{|c|}{$\mathrm{pH}^{\mathrm{a}}$} \\
\hline & $r$ & $P$ & $r$ & $P$ & $r$ & $P$ & $r$ & $P$ & $r$ & $P$ & $r$ & $P$ & $r$ & $P$ \\
\hline \multicolumn{15}{|c|}{ Fraxinus excelsior } \\
\hline Young seedlings ${ }^{\mathrm{c}}$ & 0.12 & $\mathrm{~ns}$ & -0.08 & $\mathrm{~ns}$ & -0.30 & $*$ & -0.16 & ns & 0.02 & ns & 0.08 & $\mathrm{~ns}$ & 0.21 & ns \\
\hline Old seedlings $\mathrm{c}^{\mathrm{c}}$ & 0.33 & * & -0.35 & $*$ & -0.38 & $* *$ & -0.30 & $*$ & -0.18 & ns & -0.04 & ns & 0.29 & $*$ \\
\hline Short saplings ${ }^{\mathrm{c}}$ & 0.51 & $* * *$ & -0.52 & $* * *$ & -0.31 & $*$ & -0.36 & $* *$ & -0.19 & $\mathrm{~ns}$ & -0.30 & $*$ & 0.23 & ns \\
\hline Tall saplings ${ }^{\mathrm{c}}$ & 0.34 & * & -0.48 & $* * *$ & -0.16 & ns & -0.30 & $*$ & -0.11 & $\mathrm{~ns}$ & -0.26 & $*$ & 0.30 & * \\
\hline \multicolumn{15}{|c|}{ Acer pseudoplatanus } \\
\hline Young seedlings ${ }^{c}$ & 0.00 & ns & 0.10 & ns & -0.16 & ns & -0.21 & ns & 0.23 & ns & 0.05 & $\mathrm{~ns}$ & 0.03 & ns \\
\hline Old seedlings ${ }^{\mathrm{c}}$ & 0.13 & $\mathrm{~ns}$ & -0.12 & $\mathrm{~ns}$ & -0.25 & $\mathrm{~ns}$ & -0.28 & $*$ & -0.03 & ns & -0.10 & $\mathrm{~ns}$ & -0.04 & $\mathrm{~ns}$ \\
\hline Short saplings ${ }^{\mathrm{c}}$ & 0.42 & $* *$ & -0.53 & $* * *$ & -0.27 & $\mathrm{~ns}$ & -0.25 & ns & -0.08 & $\mathrm{~ns}$ & -0.55 & $* * *$ & 0.12 & $\mathrm{~ns}$ \\
\hline Tall saplings ${ }^{\mathrm{c}}$ & 0.23 & $\mathrm{~ns}$ & -0.59 & $* * *$ & -0.10 & ns & -0.33 & $*$ & -0.38 & $* *$ & -0.43 & $* *$ & 0.42 & $* *$ \\
\hline \multicolumn{15}{|c|}{ Other trees ${ }^{b}$} \\
\hline Young seedlings ${ }^{\mathrm{c}}$ & 0.21 & $\mathrm{~ns}$ & 0.02 & $\mathrm{~ns}$ & -0.21 & ns & -0.09 & ns & 0.36 & $*$ & -0.05 & ns & -0.25 & ns \\
\hline Old seedlings ${ }^{\mathrm{c}}$ & 0.31 & * & -0.05 & $\mathrm{~ns}$ & -0.14 & ns & -0.19 & ns & 0.19 & $\mathrm{~ns}$ & -0.21 & $\mathrm{~ns}$ & -0.04 & ns \\
\hline Short saplings ${ }^{c}$ & 0.44 & $* *$ & -0.20 & $\mathrm{~ns}$ & -0.16 & ns & -0.15 & $\mathrm{~ns}$ & 0.07 & ns & -0.25 & $\mathrm{~ns}$ & -0.14 & ns \\
\hline Tall saplings ${ }^{\mathrm{c}}$ & 0.08 & $\mathrm{~ns}$ & -0.28 & $*$ & 0.09 & ns & -0.25 & $\mathrm{~ns}$ & -0.13 & $\mathrm{~ns}$ & -0.27 & $*$ & 0.21 & ns \\
\hline
\end{tabular}

a Abbreviations are: $\mathrm{CH}, \%$ cover of the herbaceous layer; $\mathrm{CT}$, \% cover of the tree layer; DF, distance to the nearest forest; DAF, distance to the nearest alluvial forest; $\mathrm{LT}$, litter thickness; $\mathrm{PD}$, plantation density; $\mathrm{pH}$, soil $\mathrm{pH}$.

${ }^{\mathrm{b}}$ Other trees are: Alnus glutinosa, Carpinus betulus, Fagus sylvatica, and Quercus robur.

c Young seedlings $(<10 \mathrm{~cm}$ tall $)$, old seedlings $(\geq 10 \mathrm{~cm}$ but $<50 \mathrm{~cm}$ tall $)$, short saplings $(\geq 50 \mathrm{~cm}$ but $<1.5 \mathrm{~m}$ tall $)$, tall saplings $(\geq 1.5 \mathrm{~m}$ tall but

$<7 \mathrm{~cm} \mathrm{dbh).}$

ns: $P>0.05 ; * 0.01<P<0.05 ; * * 0.001<P<0.01 ; * * * P<0.001$.

A. pseudoplatanus and $F$. excelsior were the most frequent/ abundant saplings. Within Beech stands, F. sylvatica, A. pseudoplatanus, F. excelsior, and $C$. betulus were rather frequent but have low abundances. In addition, the shrubs $C$. avellana, C. monogyna and S. nigra colonized stands of both clusters. Interestingly, for the two main regenerating species, i.e. A. pseudoplatanus and $F$. excelsior, none of medians of abundances observed in the three deciduous clusters were greater than the median values observed in the Ns rich group.

\subsection{Influence of environmental characteristics on the regeneration}

Concerning the regional characteristics, the density of woody juveniles of $F$. excelsior and A. pseudoplatanus were negatively correlated with the two distance measures (Tab. II) on the whole. The distance to the nearest alluvial forest had a greater explaining power than the other distance measure. This isolation effect was particularly marked for F. excelsior.

Concerning the local characteristics, Spearman rank correlations indicated that litter thickness did not so much influence densities of both seedlings and saplings of F. excelsior, A. pseudoplatanus and of other trees. On the other hand, sapling densities decreased with increasing plantation densities whereas correlations of seedling densities with the last were not significant. Correlations with percentage of cover of the tree layer led to the same results, i.e., significant negative correlations for saplings and non-significant ones for seedlings. On the contrary,

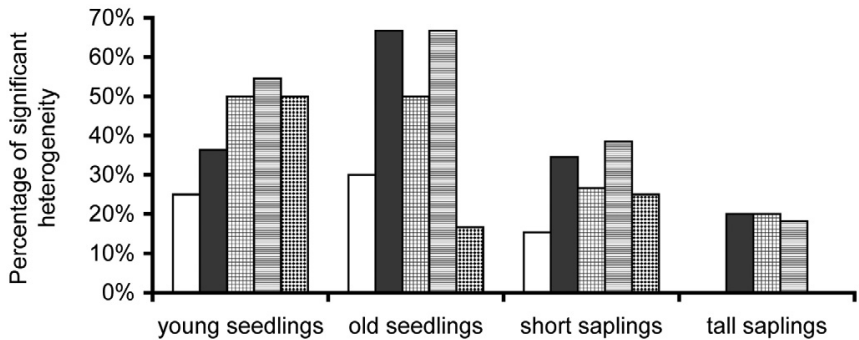

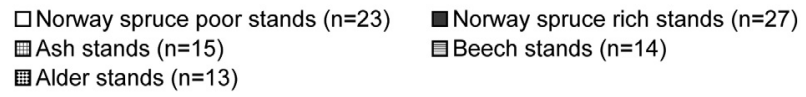

Figure 5. Percentages of stands with significant spatial heterogeneity in relation to height classes and stand types (heterogeneity assessed by the Morisita index [43]).

the cover percentage of the herbaceous layer was positively correlated with the sapling densities, and especially with the density of the short saplings. No great differences were detected between the regeneration patterns of the two main trees F. excelsior and A. pseudoplatanus. Globally, an increase of plantation densities and thus of canopy cover percentages decreased the sapling numbers. Low plantation densities allowed high sapling numbers as well as high herbaceous covers. These effects were not noticed for seedlings. 


\subsection{Heterogeneity of the regeneration}

The Morisita index showed that at least a part of the regeneration pool was aggregated (Fig. 5). However, whatever the developmental stage considered, the spatial heterogeneity observed in Norway spruce plantations was rather well comparable with that of deciduous stands. The maximum heterogeneity was reached for seedlings and decreased to less than $20 \%$ for tall saplings. For them, the Norway spruce poor group and the deciduous alder group showed no stand with significant heterogeneity, as a consequence of the low regeneration densities observed in these groups (Figs. 4a and 4c).

\section{DISCUSSION}

\subsection{Composition of the regeneration}

Natural regeneration in temperate forests often results in high seedling densities [42, 60]. Within the Ns rich group, F. excelsior and A. pseudoplatanus saplings are the main regenerating trees. The pattern of sapling regeneration in the Ns rich group is generally similar to that of Ash group (Figs. 4b and $4 d)$. The total number of useful saplings for forestry has a

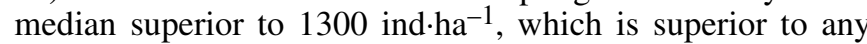
median of the deciduous clusters. In a restricted number of plantations (15\%), this number exceeds $10000 \mathrm{ind} \cdot \mathrm{ha}^{-1}$, which is much higher than the recommended afforestation rates (from 1600 to 4500 saplings $\cdot$ ha $^{-1}$ for $A$. pseudoplatanus and $F$. excelsior [6]). Some individuals of $F$. excelsior and A. pseudoplatanus even reach $15-20 \mathrm{~m}$ and seem very promising from an economic point of view. Norway spruce seedlings are quasiabsent in both Norway spruce groups (Figs. 4a and 4b). A too high moisture level of alluvial soils in winter probably leads to the death of young seedlings and therefore, a negative feedback between the mature trees and the regeneration dynamic occurs.

The autecology of F. excelsior and A. pseudoplatanus is generally similar although $A$. pseudoplatanus seems to be more tolerant to a lack of moisture in the soil than F. excelsior [9]. It is well-known that the best growth of $F$. excelsior and $A$. pseudoplatanus occurs on base-rich soils [58] which have a high moisture level [37], and on nutrient rich sites [9]. In addition, sediment texture of alluvial valleys of small rivers varies primarily with the bedrock nature. Lower Devonian layers of the Oesling have lead to fine texture deposits whereas sandstones from Triassic and Jurassic of the Gutland have lead to sandy soils. Fine texture deposits combined with lower depths of reduction level and of bedrock appearance (Tab. I) enhanced soil gleyification. Consequently, soil conditions of the Gutland (sandy, relatively high $\mathrm{pH}$, low water table) are the most appropriate for natural tree regeneration. These results also highlight the primordial importance of the biogeographical region for studying tree regeneration dynamics and hence to begin the conversion process.

\subsection{Plantation density and litter thickness}

The ground vegetation below dense plantations of young Norway spruce is often sparse because of shading [3] and the slow decomposition kinetic of the litter [13, 25]. Indeed, our results revealed the strong effect of the Norway spruce density on the spontaneous regeneration (Tab. II). The plantation density is primarily related to the management intensity, i.e. the frequency of thinning out. The higher plantation densities observed throughout the Oesling (Tab. I) are explained by the lower management intensity due to the lower accessibility of the stands (hilly area). Tree densities influence light availability for the understorey. In temperate alluvial forests, light has previously been found to be determinant for regeneration dynamics [53]. A lack of light generally decreases not only the survival [23, 50], but also the establishment and growth of forest tree species [7, 53], and especially the establishment of $F$. excelsior [42], the growth of $F$. sylvatica $[1,11,12]$, and the growth of $Q$. robur $[35,45]$. Nevertheless, some young seedlings have the ability to produce firstly shade leaves [59], which enables them to survive many years under closed canopies $[12,56]$, such as those of dense Norway spruce plantations. This may explain why Norway spruce plantation densities had lower effects on seedling numbers than on sapling densities (Tab. II). The occurrence of juveniles as a bank of persistent seedlings and saplings is primordial because these can grow very rapidly in response to canopy opening [56], allowing to overcome a competition stage with the herbaceous layer [27, 42] that occurs frequently on alluvial, nutrient-rich soils [53, 54]. From this point of view, shading is essential for limiting the occurrence of tall persistent and strongly competitive herbs such as Urtica dioica and finally for regeneration of alluvial trees [53]. Indeed, longer periods with shelterwoods [29,39] or techniques of regeneration in gaps [51] are more and more recommended in practical forestry as well as in nature conservation [24].

Higher plantation densities within the Ns poor group leads also to a higher litter production, which in turn increases the soil acidity [4]. The litter is also more persistent because of a lack of light [25]. Generally, litter has a negative effect on recruitment [21]. The lower amount of litter in Ns rich stands (Tab. I) leads to a greater part of mineral soil being exposed to the seed-rain, providing an ideal substrate for germination and growth of not only small-seeded, wind-dispersed species [20] such as Alnus glutinosa and Salix spp., but also large-seeded species such as $F$. excelsior, A. pseudoplatanus, $Q$. robur and $F$. sylvatica. Moreover, seedling emergence of small-seeded species is inhibited by litter to a much higher extent than that of large-seeded species $[20,52]$. This may explain why the main regenerating tree species are large-seeded species (Fig. 4b), for which the litter thickness does not appear to be a strong limiting factor (Tab. II).

\subsection{Dispersal and heterogeneity}

Although deciduous mother trees are very scarce in Norway spruce plantations, saplings were found everywhere in Ns rich group. Moreover, most of the forest tree species have a transient seed bank [5], to such an extent that the seed rain drives the regeneration processes even in deciduous alluvial forests [14]. Under mature Norway spruce canopy (ca. 45 years old), regenerating trees colonize thus the plantation from the outside, i.e. from the nearest forest. Ash and Maple are very abundant in floodplain forests, whereas other studied trees are located preferentially on hillside forests. Logically, young trees of the firsts were correlated with distance to the nearest alluvial forests 
(Tab. II). In Ns poor group, distances to alluvial forest were too high to ensure recruitment, despite the strong dispersal abilities of Fraxinus sp. and Acer sp. [33]. Thus, availability of seeds in surroundings (regional factor) determined the successful colonization of the Norway spruce plantations to an extent at least comparable to the availability of micro-sites suitable for seeds germination and tree development (local factor). Further studies could aim at distinguishing the relative effects among the regional and local factors pointed out in this study.

The aggregation index of Morisita showed certainly a significant spatial heterogeneity for Norway spruce regeneration, but this heterogeneity was rather similar to that observed in deciduous forests (Fig. 5). Firstly, many deciduous trees are characterized by intermittent production of mast seeding [32, 36]. For example, the fruiting irregularity of $F$. excelsior is related to predator satiation [55]. Such a temporal variability improves the spatial homogeneity because mast fruiting years occur synchronously within the population $[32,57]$. Secondly, the Morisita index decreases strongly when the seedlings become older. Indeed, young seedlings are often patchy distributed because of spatial variation of tree fruiting. That leads to high values of the index. In time, only a few seedlings will become saplings due to competition, and that whatever the initial densities, hence the heterogeneity will decrease.

\section{CONCLUSION}

This study has demonstrated that Norway spruce stands with high density and on acidic soils were not relevant candidate for a conversion process. On the other hand, Norway spruce plantations with low density, located on alluvial base-rich soils (local factors) and close to seed sources (regional factor) strongly favoured a suite of broad-leaved riverine tree species. Taking advantage of the natural regeneration processes and applying only a few silvicultural measures will lower conversion energy and forestry costs (i.e. soil preparation, direct sowing, supplementary planting and regulation of tree composition) [26]. For the development of mixed and multifunctional forest stands, with a high ecological and landscape value, the spontaneous regeneration provides an interesting conversion mean. We recommend that further studies are carried out for a better understanding of the ecological processes within coniferous plantations such as seed dispersal, predation and germination, seedling establishment and growth, the influence of browsing [e.g. 16] and also of the effects of management practices [51].

Acknowledgements: B.H. was supported by a doctoral grant (BFR01/060) from the 'Ministère de la Culture, de l'Enseignement Supérieur et de la Recherche (Luxembourg)', and by the following institutions in Luxembourg: 'Administration des Eaux et Forêts', 'Musée national d'histoire naturelle'. We are grateful to F. Lemmens for her help during data collecting and to L. Augusto and an anonymous reviewer for useful comments on the manuscript.

\section{REFERENCES}

[1] Ammer C., Growth and biomass partitioning of Fagus sylvatica L and Quercus robur $\mathrm{L}$. seedlings in response to shading and small changes in the R/FR-ratio of radiation, Ann. For. Sci. 60 (2003) 163-171.

[2] Ashton P.M.S., Gamage S., Gunatilleke I.A.U.N., Gunatilleke C.V.S., Restoration of a Sri Lankan rainforest: using Carribean pine Pinus caribaea as a nurse for establishing late-successional tree species, J. Appl. Ecol. 34 (1997) 915-925.

[3] Augusto L., Dupouey J.-L., Picard J.-F., Potential contribution of the seed bank in coniferous plantations to the restoration of native deciduous forest vegetation, Acta Oecol. 22 (2001) 87-98.

[4] Augusto L., Ranger J., Binkley D., Rothe A., Impact of several common tree species of European temperate forests on soil fertility, Ann. For. Sci. 59 (2002) 233-253.

[5] Bossuyt B., Hermy M., Influence of land use history on seed banks in European temperate forest ecosystems: a review, Ecography 24 (2001) 225-238.

[6] Boudru M., Forêt et sylviculture, sylviculture appliquée, Les Presses Agronomiques de Gembloux, Gembloux, 1986.

[7] Catovsky S., Bazzaz F.A., Feedbacks between canopy composition and seedling regeneration in mixed conifer broad-leaved forests, Oikos 98 (2002) 403-420.

[8] Chytrý M., Otýpková Z., Plot sizes used for phytosociological sampling of European vegetation, J. Veg. Sci. 14 (2003) 563-570.

[9] Claessens H., Pauwels D., Thibaut A., Rondeux J., Site index curves and autecology of ash, sycamore and cherry in Wallonia (Southern Belgium), Forestry 72 (1999) 171-182.

[10] Clark J.S., Beckage B., Camill P., Cleveland B., HilleRisLambers R., Lichter J., McLachlan J., Mohan J., Wyckoff P., Interpreting recruitment limitation in forests, Am. J. Bot. 86 (1999) 1-16.

[11] Coll L., Balandier P., Picon-Cochard C., Prévosto B., Curt T., Competition for water between beech seedlings and surrounding vegetation in different light and vegetation composition conditions, Ann. For. Sci. 60 (2003) 593-600.

[12] Collet C., Lanter O., Pardos M., Effects of canopy opening on height and diameter growth in naturally regenerated beech seedlings, Ann. For. Sci. 58 (2001) 127-134.

[13] Cornelissen J.H.C., An experimental comparison of leaf decomposition rates in a wide range of temperate plant species and types, J. Ecol. 84 (1996) 573-582.

[14] Deiller A.F., Walter J.M.N., Trémolières M., Effects of flood interruption on species richness, diversity and floristic composition of woody regeneration in the upper Rhine alluvial hardwood forest, Regul. River 17 (2001) 393-405.

[15] Diaci J., Regeneration dynamics in a Norway spruce plantation on a silver fir-beech forest site in the Slovenian Alps, For. Ecol. Manage. 161 (2002) 27-38.

[16] Drexhage M., Colin F., Effects of browsing on shoots and roots of naturally regenerated sessile oak seedlings, Ann. For. Sci. 60 (2003) 173-178.

[17] Duchaufour P., Pédologie. 1. Pédogénèse et classification, Masson, Paris, 1967.

[18] Dufrêne M., Legendre P., Geographic structure and potential ecological factors in Belgium, J. Biogeogr. 18 (1991) 257-266.

[19] Dufrêne M., Legendre P., Species assemblages and indicator species: the need for a flexible asymmetrical approach, Ecol. Monogr. 67 (1997) 345-366.

[20] Dzwonko Z., Gawronski S., Influence of litter and weather on seedling recruitment in a mixed oak-pine woodland, Ann. Bot. 90 (2002) 245-252.

[21] Facelli J.M., Pickett S.T.A., Plant litter: its dynamics and effects on plant community structure, Bot. Rev. 57 (1991) 1-32.

[22] FRA, The forest resources of the temperate zones. Benefits and functions of the forests, United Nations, New York, 1990. 
[23] Grubb P.J., Lee W.G., Kollman J., Wilson J.B., Interaction of irradiance and soil nutrient supply on growth of seedlings of ten European tall-shrub species and Fagus sylvatica, J. Ecol. 84 (1996) 827 840.

[24] Hannerz M., Hånell B., Effects on the flora in Norway spruce forests following clearcutting and shelterwood cutting, For. Ecol. Manage. 90 (1997) 29-49.

[25] Heitz R., Rehfüss K.E., Reconversion of Norway spruce (Picea abies (L.) Karst.) stands into mixed forests: effects on soil properties and nutrient fluxes, in: Olsthoorn A.F.M., Bartelink H.H., Gardiner J.J., Pretzsch H., Hekhuis H.J., Franc A. (Eds.), Management of mixed-species forest: silviculture and economics, DLO Institute for Forestry and Nature Research (IBN-DLO), Wageningen, 1999, pp. 46-57.

[26] Hekhuis H.J., Wiemann E.A.P., Costs, revenues and function fulfilment of nature conservation and recreation values of mixed, uneven-aged forests in The Netherlands, in: Olsthoorn A.F.M., Bartelink H.H., Gardiner J.J., Pretzsch H., Hekhuis H.J., Franc A. (Eds.), Management of mixed-species forest: silviculture and economics, DLO Institute for Forestry and Nature Research (IBN-DLO), Wageningen, 1999, pp. 331-346.

[27] Helliwell D.R., Harrison A.F., Effects of light and weed competition on the growth of seedling of four tree species on a range of soil, Q. J. For. 73 (1979) 160-171.

[28] Hérault B., Bouxin G., Thoen D., Comparison of the regeneration patterns of woody species between Norway spruce plantations and deciduous forests on alluvial soils, Belg. J. Bot. 137 (2004) 36-46.

[29] Holgén P., Hånell B., Performance of planted and naturally regenerated seedlings in Picea abies-dominated shelterwood stands and clearcuts in Sweden, For. Ecol. Manage. 127 (2000) 129-138.

[30] Honnay O., Bossuyt B., Verheyen K., Butaye J., Jacquemyn H., Hermy M., Ecological perspectives for the restoration of plant communities in European temperate forests, Biodivers. Conserv. 11 (2002) 213-242.

[31] Hurlbert S.H., Pseudoreplication and the design of ecological experiment, Ecol. Monogr. 54 (1984) 187-211.

[32] Iwasa Y., Satake A., Mechanisms inducing spatially extended synchrony in mast seeding: the role of pollen coupling and environmental fluctuation, Ecol. Res. 19 (2004) 13-20.

[33] Johnson W.C., Estimating the dispersability of Acer, Fraxinus and Tilia in fragmented landscapes from patterns of seedling establishment, Landscape Ecol. 1 (1988) 175-187.

[34] Kazda M., Pichler M., Priority assessment for conversion of Norway spruce forests through introduction of broadleaf species, For. Ecol. Manage. 102 (1998) 245-258.

[35] Kazda M., Wagner C., Pichler M., Hager H., Potentielle Lichtausnützung von Quercus petraea, Fagus sylvatica und Acer pseudoplatanus im Jahr des Voranbaus, Allg. Forst u. J.-ztg 169 (1998) $157-162$.

[36] Kelly D., The evolutionary ecology of mast seeding, Trends Ecol. Evol. 9 (1994) 465-470.

[37] Kerr G., Cahalan C., A review of site factors affecting the early growth of ash (Fraxinus excelsior L.), For. Ecol. Manage. 188 (2004) 225-234.

[38] Lambinon J., Delvosalle L., Duvigneaud J., Nouvelle flore de la Belgique, du Grand-Duché de Luxembourg, du Nord de la France et des régions voisines (Ptéridophytes et Spermatophytes), Éditions du Patrimoine du Jardin botanique national de Belgique, Meise, 2004.

[39] Löf M., Gemmel P., Nilsson U., Welander N.T., The influence of site preparation on growth in Quercus robur $\mathrm{L}$. seedlings in a southern Sweden clear-cut and shelterwood, For. Ecol. Manage. 109 (1998) 241-249.

[40] Lust N., Kongs T., Nachtergale L., De Keersmaeker L., Spontaneous ingrowth of tree species in poplar plantations in Flanders, Ann. For. Sci. 58 (2001) 861-868.
[41] McCune B., Mefford M.J., PC-ORD. Multivariate analysis of ecological data, Version 4, MjM Software Design, Gleneden Beach, 1999.

[42] Modrý M., Hubený D., Rejšek K., Differential response of naturally regenerated European shade tolerant species to soil type and light availability, For. Ecol. Manage. 188 (2004) 185-195.

[43] Morisita M., Measuring of the dispersion and analysis of distribution patterns, Memoires of the Faculty of Science, Kyushu University, Series E, Biology 2 (1959) 215-235.

[44] Mosandl R., Kleinert A., Development of oaks (Quercus petraea (Matt.) Liebl.) emerged from bird-dispersed seeds under oldgrowth pine (Pinus silvestris L.) stands, For. Ecol. Manage. 106 (1998) 35-44.

[45] Niinemets U., Growth of young trees of Acer platanoides and Quercus robur along a gap-understory continuum: interrelationships between allometry, biomass partitioning, nitrogen, and shade tolerance, Int. J. Plant Sci. 159 (1998) 318-330.

[46] Noirfalise A., Sougnez N., Les forêts riveraines de Belgique, Bull. Jard. Bot. État 30 (1961) 199-288.

[47] Noirfalise A., Thill A., Les boisements d'épicéa et leurs types pédobotaniques en Ardenne (Belgique), Beitr. Naturk. Foresch. Südw.Dtl. 34 (1975) 251-257.

[48] Parotta J.A., Influence of overstory composition on understory colonization by native species in plantations on a degraded tropical site, J. Veg. Sci. 6 (1995) 627-636.

[49] Pier J., Les forêts alluviales au Grand-Duché de Luxembourg, Musée d'Histoire Naturelle, Luxembourg, 1989.

[50] Sack L., Grubb P.J., Why do species of woody seedlings change rank in relative growth rate between low and high irradiance? Funct. Ecol. 15 (2001) 145-154.

[51] Schütz J.-P., Opportunistic methods of controlling vegetation, inspired by natural plant succession dynamics with special reference to natural outmixing tendencies in a gap regeneration, Ann. For. Sci. 61 (2004) 149-156.

[52] Seiwa K., Kikuzawa K., Importance of seed size for the establishment of seedlings of five deciduous broad-leaved tree species, Vegetatio 123 (1996) 51-64.

[53] Siebel H.N., Bouwma I.M., The occurrence of herbs and woody juveniles in a hardwood floodplain forest in relation to flooding and light, J. Veg. Sci. 9 (1998) 623-630.

[54] Smit R., Olff H., Woody species colonisation in relation to habitat productivity, Plant Ecol. 139 (1998) 203-209.

[55] Tapper P.G., Irregular fruiting in Fraxinus excelsior, J. Veg. Sci. 3 (1992) 41-46.

[56] Tapper P.G., Demography of persistent juveniles in Fraxinus excelsior, Ecography 15 (1992) 385-392.

[57] Tapper P.G., Long-term patterns of mast fruiting in Fraxinus excelsior, Ecology 77 (1996) 2567-2572.

[58] Weber-Blaschke G., Claus M., Rehfuess K.E., Growth and nutrition of ash (Fraxinus excelsior L.) and sycamore (Acer pseudoplatanus L.) on soils of different base saturation in pot experiments, For. Ecol. Manage. 167 (2002) 43-56.

[59] Welander N.T., Ottosson B., The influence of shading on growth and morphology in seedlings of Quercus robur L. and Fagus sylvatica L., For. Ecol. Manage. 107 (1998) 117-126.

[60] Zerbe S., Restoration of natural broad-leaved woodland in Central Europe on sites with coniferous forest plantations, For. Ecol. Manage. 167 (2002) 27-42.

[61] Zerbe S., Vegetation and future natural development of plantations with the Black poplar hybrid Populus $\times$ euramericana Guinier introduced to Central Europe, For. Ecol. Manage. 179 (2003) 293 309. 